\title{
Non-Penal Policy in Crime Prevention Through Moral/Educational/Religious Approach
}

\author{
$\operatorname{Rasdi}^{1}$ \\ \{mr.rasdi@mail.unnes.ac.id\} \\ Faculty of Law, Universitas Negeri Semarang, Semarang, Indonesia ${ }^{1}$
}

\begin{abstract}
Crime is the oldest and most complex social problem, as it requires an integrated coping strategy/effort, between penal and non-penal means. It is because of the limited ability of the penal means in dealing with crime. On the other hand, crime prevention is essentially also part of efforts to protect society (social defense planning or protection of society) and an effort to achieve social welfare. Non-penal policy through moral/educational/religious approach in crime prevention in Indonesia occupies a very strategic position.
\end{abstract}

Keywords: Non-penal policy; moral/educational/religious approach.

\section{Introduction}

Crime is a form of deviant behavior [1], which is always present and attached to the community [2] and becomes a real or potential threat to the sustainability of social order. It has its form of human actions [3] from time to time to change according to the conditions of society. The society has a type/form of crime in accordance with its culture, morals, beliefs and social, economic, political, and existing structures and create/construct their own types/form of crime. [4] Thus, crime is a problem that is closely related to humanitarian and social aspects. [5]

Crime as "the oldest social problem" [6] requires prevention efforts through penal policy, rationally and comprehensively. Efforts to tackle crime are essentially an integral and inseparable part of efforts to protect society (social defense planning or protection of society) and an effort to achieve social welfare. [7]

Based on the foregoing, main goal/ultimate goal of criminal politics is protection of society to achieve social welfare. Such objectives are in line with the report of the $34^{\text {th }}$ training course by UNAFEI in Tokyo in 1973 as follows: [8]

"Most of group members agreed some discussion that 'protection of the society' could be accepted as the final goal of criminal policy, although not the ultimate aim of society, which might perhaps be discribed by terms like'happines of citizen', a wholesome and cultural living, social welfare or equality".

Based on the above report, it can be stated that criminal politic is essentially an integral part of social politics, which is a policy to achieve social welfare. Therefore, crime prevention policy (criminal politic) can cover a wide-ranging scope. According to Barda Nawai Arief, crime prevention can be done through: [9]

a. Criminal law application

b. Prevention without punishment

c. Influencing views of society on crime and punishment/mass media.

Broadly speaking, crime prevention can be pursued through 2 (two) paths, which are "penal" (penal law) path and "non-penal" path (extra-/non-penal law). Crime prevention through the penal path is more focused on the repressive approach in the form of suppression, eradication and extermination, after the crime is committed. While the "non-penal" path puts more emphasis on the "preventive" nature of prevention, deterrence and control before the crime is committed/occurred. Thus, non-penal path is more directed or targeted at the conducive factors as 
the cause of crime. It underlines social problems that can foster crime. Therefore, this non-penal path is regarded to be occupying a strategic position of the entire criminal political effort.

One of the "non-penal" paths to deal with social problems is through social policy, which G. P. Hoefnagels has included in the path of prevention without punishment. Social policy can include problems such as mental health, national mental health, and child welfare.

Prof. Sudarto stated that crime prevention through preventive measures was carried out without the use of penal law. For example, through the Youth Organization (Karang Taruna) activities, where the youths spend their free time outside the home and school in order to avoid deviant/malevolent behavior, in which Scouting and community mental health cultivation with religious education are non-penal efforts that can prevent and tackle crime. [10]

In this paper we will examine: How is non-penal policy through moral/educational/religious approach to crime prevention in Indonesia?

\section{Result and Discussion}

\subsection{Urgency of Non-Penal Policy}

Penal policy is part of law enforcement policy in the broadest sense [11] Prof. Sudarto as written by Prof. Pujiyono stated that crime prevention policies or commonly referred to as criminal politics (criminal policy) are essentially rational efforts of the community in tackling crime. [12]

In the context of tackling crime in the community, various forms of social reactions or responses are available, which can be pursued through 2 (two) means, which are penal means (penal law) and non-penal means (extra-/non-penal law). [13] Through the penal path, crime prevention is more focused on its repressive nature (suppression/eradication/extermination) after the crime is committed. Whereas through non-penal path, crime prevention put more focus on its preventive nature (prevention/deterrence/ control) before the crime is committed.

The results of the study indicates that law policies are generally sufficient and effective, but there are deficiencies in the limited liability schemes in Indonesia, as well as uncertainty about the types of violations in civil or criminal enforcement. [14] Therefore, it is necessary to make a draft bill with a careful and calculative basis and without being emotional in determining a criminal act/criminal offense. [15]

The crime of terrorism in China with the influence of religious extremism has used crime and violence as a means of creating terror and spreading panic to achieve their goals, which is to disunite the State of China. Meanwhile the use of penal law is an effective instrument to combat these crimes. The characteristics of terrorism in China require reconstruction of a penal law system related to the model of criminal punishment with intentional elements, by introducing terrorist motivation into constitutive elements of terrorism crimes. [16]

Prof. Barda Nawawi Arief stated that the integral policy in crime prevention includes "all rational efforts to deal with crime must be an integrated unity." It means that policies to tackle crime by using criminal sanctions must also be integrated with other "non-penal" efforts in nature. [17] While Prof. Suharto related to integral policy issues clarified that the influence and ability of the penal law is limited, therefore the protection of the community needs to use other means besides penal law. [18]

Furthermore, Prof. Barda Nawawi Arief, in Kartono's article [19] identified several limited ability of penal law to deal with crime as follows:

a. This type/form of crime is complex beyond the scope of penal law.

b. Penal law is only a small part (sub-system) of social control means, which is unlikely to overcome the problem of crime as very complex human and social problem (as sociopsychological, socio-political, socio-economic, socio-cultural problems, etc.);

c. The use of penal law in dealing with crime is only "kurrien am symptom," therefore it is only "symptomatic remedy" and it is not "causative remedy";

d. Penal law sanctions are "remidium" which contain contradictory/ paradoxical nature and encompass negative elements and side effects;

e. Punishment system is fragmentair and individual/personal, rather than 
structural/functional;

f. The limited types of criminal sanctions and the rigid and imperative formulation systems of criminal sanctions in nature;

g. Operation/functioning of penal law requires a variety of supporting facilities that are more demanding "high costs". Given these limitations, "the use of a means of penal in crime prevention should be done with careful consideration".

In using the means of penal, Nigel Walker once reminded the existence of "limiting principles" that rightly needs more attention, including:

a. Penal law shall not be solely used for the purpose of retaliation;

b. Penal law shall not be used to convict an unharmful/non-threatening act;

c. Penal law shall not be used to achieve a goal that can be achieved more effectively with easier means;

d. Penal law shall not be used in the event that the damages/hazard arising from the crime is greater than the damages/hazard from the act/crime itself;

e. Penal law prohibitions shall not carry more dangerous characteristics than acts that will be prevented;

f. Penal law shall not contain restrictions that have no strong support from the public.[20]

By considering the various limited ability of penal law as the above-mentioned means of penal, it is necessary to take other means by using preventive non-penal means in tackling the increasingly complex and modern crimes. Both of these means, by the means of penal and nonpenal, must be a balanced and proportional integration in the sense that they are adapted to the form and type of crime to be prevented so that they can achieve effective results.

According to Prof. Muladi, certain crime prevention strategies are often specific in nature, deviating from general penal law principles such as dealing with serious crimes such as criminal acts of corruption, terrorism, money laundering, serious human rights violations and others. [21] It has also been done by the Government of Rome (Italy), as there is a special regulatory model for crime prevention with victims and special actors (minorities).[22]

On another occasion Prof. Barda Nawawi Arief also emphasized the need for "reevalution", "review", "reorientation", "reform" and "reformulation" in all criminal policies, bearing in mind that the criminal legal system being charged by foreign countries is also a colonial legacy that it is the time to adjust with cultural values, as there is even discrepancy with people's aspirations.[23]

\subsection{Non-Penal Policy through Moral/Educational/Religious Approach}

The impact of the implementation of development that is not planned rationally or carried out in an unequal manner that does not take into account the balance of various aspects of social life will become a criminogen factor (unbalanced/inadecuately planned). It includes overlooking cultural and moral values (disregarded cultural and moral values), and did not include integrated social defense strategies.[24]

In consideration of Resolution No. 3 of the $6^{\text {th }}$ UN Congress of 1980 on the "Effective Measures to Prevent Crime", among others, emphasized: [25]

1. Crime prevention is highly subject to the human personal himself (that crime prevention is dependent on man himself).

2. Crime prevention strategies must be based on efforts to raise people's spirits or souls and strengthen their confidence in their ability to do good. (that crime prevention strategies should be based on exalting the spirit of man and reinforcing his faith in his ability to do good).

On the basis of the above facts, then the UN focused its attention on efforts to strengthen human confidence in its ability to follow the path of truth/goodness.

If examined closely, it will be clearly seen that the UN resolution put an emphasis on how important the role of education, religious education and various forms of religious activities are, in order to strengthen the path of truth and goodness. Through effective forms of educational activities and religious counseling, it will give birth to human beings who are spiritually/mentally 
healthy. Thus in turn it will be able to materialize the formation of a whole healthy family and produce a healthy social environment as well.

On the other hand, it is emphasized the need to explore, develop and utilize all the potential support and participation of the community to utilize and develop the "extra legal system" and "informal and traditional system" that exist in the society. As stated in the UN Congress on "The Prevention and Treatment of Offenders". In the $4^{\text {th }}$ UN Congress, regarding "Non-judicial forms of social control", emphasized that: [26]

"It was important that traditional forms of primary social control should be revived and developed".

In the "Guiding Principles" results of the $7^{\text {th }}$ UN Congress, regarding the "traditional forms of social control" also confirmed that: [27]

"When new crime prevention are measure introduced, necessary precautions should be taken not to disrupt the smooth and effective functioning of traditional system, full attention being paid to the preservation of cultural identities and the protection of human rights"

Moral development theory classifies moral thinking including 3 (three) stages: preconvetional stage, convetional level and postconventional level.[28] At the preconventional stage, children are inculcated with moral values at the command to commit or not to commit an act that violates the rules or the law in order to avoid punishment/sanctions. This stage is generally the education of parents carried out in the house by example from parents/family. Even parents are willing to serve the needs of children with various efforts. On the negative side, however, while parents are willing to commit deviant acts, parents charged with a criminal offense had higher rates of having a Child Protectives Services assessment/investigation. [29]

Getting into the conventional stage, a teenager or an individual has entered the stage of believing and adopting moral values and rules that exist in society. They go further to enforce these rules and think "stealing is illegal/breaking the law", so they do not commit theft in any circumstances. Then in the final stage of postconventional level, individuals have been able to think critically to examine social habits or rules according to their feelings about universal human rights, moral principles and moral obligations. They have been able to think carefully that every individual in society should obey the rules and at the same time hold universal ethical and moral principles. They have been able to respect human rights and the dignity of human life.

Thus, it can be understood that the process of the stages of moral development as mentioned above is naturally holistically possible to be carried out starting from the process of life/education in the family (informal education), school (formal education) and education in society (non formal education).

In scouting education carried out in schools ranging from elementary, junior high, senior high school and even college, tri darma and dasa darma has been taught, which contains moral, religious and social life teachings. After participating in scouting education they are expectedly able to apply the values of goodness and truth teaching (moral values and religious values :red.) to be applied in daily life in the society.

Armed with the values that the scouting education has taught, they will be able to avoid committing despicable acts or other deviant acts such as those that occur with the use/consumption of very harmful drugs for the future of the children/adolescents themselves.[30]

In the modern/millennial era as it is today, it is marked by rapid growth of technological developments, especially telecommunications technology and computer technology with a multifunctional internet network, leading everyone to think in an unlimited direction (borderless way of thinking).[31] The era of globalization has presented the role of information technology in a very strategic position, capable to present a world without limits, distance, space, and time and can increase productivity and efficiency. The emergence of information technology has changed the pattern of people's lives globally and has caused significant changes in rapidly increasing socio-cultural, economic, and legal frameworks. The presence of information technology presents a dilemma as well. On the one hand, it contributes to the improvement of human welfare, progress and civilization, but on the other hand, it can be an effective means of committing crime.

One negative impact of the advancement of information technology with computerized systems and internet networks that is and continues to spread in the world community and 
particularly the Indonesian Nation is cyber crime in the field of decency, which is more popular with the term of cyber porn.[32] As a result of the rampant spread of pornography among Indonesian people so that it has been very troubling, especially with the emergence of various other types of crime. Many young people are involved in promiscuity (free sex), cases of molestation, rape, the emergence of LGBT groups (Lesbian, Gay, Bisexual, Transgender), online prostitution and so forth.

Commercial sex workers under penal code (KUHP) are indeed problematic (lack of rules) that are charged with criminal sanction. Therefore, there is a need for new rules in the Penal Code to provide an effect deterence (prevention) on the proliferation of prostitution practices. There is a balance between sex workers/perpetrators and service providers in their criminal regulation.[33] Unlike in Spain, new special regulations on street prostitution can be charged with criminal sanction. [34]

Certainly, the phenomenon of the flourishing crimes/deviant behavior as mentioned above is very contrary to the moral values of religious, ethics and culture of Indonesian society. Religious morality occupies very important position, as there is a close relation between religious institutions and crime. [35] Therefore, religion is a fundamental variable in determining the causes of crime.

Free sex (extra-marital sexual intercourse) is very contrary to the sacred and highly respected marriage institution according to the cultural values in Indonesian society. It is different in European countries or other ones as they have their cultures to live together without being married, so that they will pass down the culture of free sex and free love to their children. They no longer believe in what marriage is or most of them apply the culture of living together without being married. [36] Religious norms have forbidden the act of promiscuity (adultery), as stated in the Qur'an Surah Al-Isra' verse 32, which states:

"And do not approach unlawful sexual intercourse. Indeed, it is ever an immorality and is evil as a way."

Because the act of adultery is extra-marital intercourse between men and women that violates decency, damages offspring, causes sexually transmitted diseases, leading to disputes, family disharmony, and other disasters. [37]

In Qur'an Surah An-Nur Verse 2, firmly states that:

"The woman or man found guilty of sexual intercourse - lash each one of them with a hundred lashes, and do not be taken by pity for them in the religion of Allah, if you should believe in Allah and the Last Day. And let a group of the believers witness their punishment."

Regarding the story of Punk kids [38], with tattoos all over their bodies, and red-colored hairs and pierced ears, they gather in front of Tebet Station with a guitar, not for busking, but for Qur'an recitation. They gathered on the command of Tasawuf Underground, a religious community targeting punk kids. By laying out makeshift mats, the religious community (Tasawuf Underground) gather to spread religious lectures on punk kids under the bridge. The concept of the presented Qu'ran is not as usual as in Islamic boarding schools/in Al-Qur'an Education Center, which merely learn to read the Qur'an, but also recite about life, imprinting them with a clean and true heart. It aims that punk kids will have the skills to survive and move away from street life, which by the view of the community is considered synonymous with children who commit crimes/other deviant acts. Some opinions even state that the solution for crime prevention is to provide children with the moral, love and discipline guidelines they need to grow into healthy adults.[39] Based on the above facts, learning through the moral/religious approach it turns out that it is able to be an effective means to change one's attitudes and behavior from patterns of deviant (malevolent) thought/way of life to migrate to the path of truth and goodness.

\section{Conclusion}

Based on the discussion and analysis above, it can be concluded as follows: 
1. Crime prevention policies in Indonesia must be carried out integrally between the use of penal and non-penal means, given the limited use of penal means in increasingly complex crime prevention.

2. The use of non-penal means through moral/educational/ religious approach in crime prevention in Indonesia with its characteristics and complexity is an appropriate and effective approach to use by keeping in mind the strong moral, social and religious values in society.

\section{References}

[1] Sadli, Saparinah, Persepsi Sosial Mengenai Perilaku Menyimpang, 1976, pg.56, in Muladi and Barda Nawawi Arief, Teori-teori dan Kebijakan Pidana, (Bandung: Alumni, 1998), pg.148.

[2] Arief, Barda Nawawi, Kebijakan Legislatif Dalam Penanggulangan Kejahatan dengan Pidana Penjara, (Yogyakarta: Genta Publishing, 2010), pg.11.

[3] Sudarto, Kapita Selekta Hukum Pidana, (Bandung: PT Alumni,1986), pg.107.

[4] Susanto I.S, Kriminologi, (Yogyakarta: Genta Publishing, 2011), pg. 74

[5] Ancel, M., Social Defence, 1965, hal.99, dalam Muladi dan Barda Nawawi Arief, Op. Cit.

[6] Ravena H. Dey dan Kristian, Kebijakan Kriminal (Criminal Policy), (Jakarta: Kencana, 2017), pg.1.

[7] Arief, Barda Nawawi, Bunga Rampai Kebijakan Hukum Pidana: Perkembangan Penyusunan Konsep KUHP Baru, (Jakarta: Kencana, 2011), pg.4.

[8] Barda Nawawi Arief, Ibid

[9] Kenedi, John Kebijakan Kriminal (Criminal Policy) dalam Negara Hukum Indonesia, Ali Imran: Jurnal Pemerintahan dan Politik Islam, Vol. 2, No. 1 tahun 2017, pg.17

[10] Sudarto, Kapita Selekta Hukum Pidana, (Bandung: Alumni,1986), pg.114.

[11] Julianthy Evlyn Martha et al., Kebijakan Kriminal Dalam Penanggulangan Penyelundupan Manusia d i Indonesia, Jurnal Ilmu Hukum Pascasarjana Universitas Syiah Kuala, Volume 2, No. 3, Agustus 2014, pg. 29.

[12] Pujiyono, Rekonstruksi Sistem Peradilan Pidana Indonesia, (Semarang: Penerbit Pustaka Magister, 2012), pg.10.

[13] Putra Jaya, Nyoman Serikat, Pembaharuan Hukum Pidana, (Semarang: Pustaka Rizki Putra,2017), pg.28.

[14] Zhu, Ling dan Zhuo, Ruixuan, A survey of the legal and policy framework for controlling, compensating, and criminalizing ship-source pollution in Hong Kong, Marine Policy 76 (2017), pg. 38 .

[15] Persak, Nina. Beyond public punitiveness: The role of Emotions in Criminal Law Policy, International Journal of Law, Crime and Justice 57 (2019), pg. 55

[16] Jian K., et al, The establishment of the Absichtsdelikte model of criminal law

[17] Barda Nawawi Arief, Bunga Rampai Kebijakan Hukum Pidana: Perkembangan Penyusunan Konsep KUHP Baru, (Jakarta: Kencana, 2008), pg. 3-4.

[18] Sudarto, Hukum dan Hukum Pidana, (Bandung: Alumni, 1977), pg. 103.

[19] Kartono, Politik Hukum Pidana Melalui Sarana Non-Penal Dalam Penanggulangan Kejahatan di Bidang Pendidikan, Jurnal Surya Kencana Satu: Dinamika Masalah Hukum dan Keadilan Vol. 7 No. 1, Maret 2017, pg.74.

[20] Muladi dan Sulistyani RS Diah, Kompleksitas Perkembangan Tindak Pidana dan KebijakanKriminal (Bandung: Alumni, 2016), pg.155. 
[21] Nafstad, I. The Ideal Minority Victim - Roma in Swedish Criminal Courts, International Journal of Law, Crime and Justice 58 (2019), pg.10

[22] Arief, Barda Nawawi, Kapita Selekta Hukum Pidana, (Bandung: Citra Aditya Bhakti, 2003), pg. 46.

[23] Sixth UN Congress, Report, 1981, pg. 42 dan 54, dokumen A/CONF.121/L.15, Seventh UN Congress, pg.2. in Barda Nawawi Arief, Op.Cit., pg.50.

[24] Sixth UN Congress, in Barda Nawai Arief, Ibid., pg.51.

[25] Fourth UN Congress, Report, 1971, hlm.24, dalam Barda Nawawi Arief, Ibid., hal.53.

[27] Seventh UN Congress, Guiding Principles for Crime Prvention and Criminal Justice in the Context of Development and a New International Economic Order, UN Departement of Public Information, August 1988, hlm.15, dalam Barda Nawawi Arief, Ibid.

[28] Santoso Topo dan Zulfa, Eva Achjanti. Kriminologi, (Depok: Rajawali Press,2017), hal. 53

[29] Gifford, E.J., et al., Mothers and fathers in the criminal justice system and children's child protective services involvement, Child Abuse \& Neglect 101 (2020), hal.1.

[30] Sanmartin, M.X. et al., Foster care admissions and state-level criminal justice-focused prenatal substance use policies, Children and Youth Services Review 102 (2019) hal.106.

[31] Prastini, Endang Kebijakan Kriminal Pemerintah terhadap Dunia Maya (cyber crime) di Indonesia, Jurnal Surya Kencana Dua: Dinamika Masalah Hukum dan Keadilan Volume 5 Nomor 2 Desember 2018, hal.595.

[32] Manurung, Harold Agusto dkk, Analisis Yuridis Kejahatan Pornografi (Cyberporn)sebagai Kejahatan Transnasional, Diponegoro Law Jurnal, Volume 5, Nomor 3, Tahun 2016, hal.2.

[33] Nash, M. The art of deception e UK public protection policy and the criminal justice 'crisis' of 2006, International Journal of Law, Crime and Justice 38 (2010), hal. 91.

[34] Villacampa, Carolina dan Torres, Nuria. Effects of the criminalizing policy of sex work in Spain, International Journal of Law, Crime and Justice 41 (2013), hal.388.

[35] Sutherland E.H. et.al, Principles of Criminology, Eleventh Edition, English translation by: Tri Wibowo BS, (Jakarta: Prena Media Group,2018)

[36] Soponyono, Eko, Kebijakan Kriminalisasi "Kumpul Kebo" Dalam Pembangunan Hukum Pidana Indonesia, Jurnal Masalah-Masalah Hukum Undip, Ji1id 42, No. 2, April 2013, pg.198.

[37] Kartono, Kartini Patologi Sosial, (Jakarta: Raja Grafindo Persada, 2005), pg.212.

[38] m.kumparan.com, Tasawuf Underground: Ajak Punk Ngaji di Kolong Jembatan, accessed on $8^{\text {th }}$ Februari 2020, at 19.26.wib.

[39] Lilly, J. Robert et. al., Criminological Theory: Contexts and Consequences, Fifth Edition, English transalate by Tri Wibowo BS, (Jakarta: PT. Adhitya Andrebina Agung, 2015), pg.376. 